\title{
ПРОФЕСІЙНА ПІДГОТОВКА МАЙБУТНІХ ХІМІКІВ ЯК ПЕДАГОГІЧНА ПРОБЛЕМА
}

\begin{abstract}
У статті здійснено теоретичний аналіз і диференціацію понять «професійна підготовка хіміків», «професійна компетентність», «педагогічні умови формування професійної компетентності хіміків». Наголошено на тому, щуо, незважаючи на значну кількість публікачій, присвячену дослідженню понять «професійна підготовка», «професійна компетентність» $i$ «педагогічні умови», у науково-педагогічній літературі спостерігається неоднозначність їх трактувань. Компетентність у дослідженні визначається як певний рівень компетенцій, професійна компетентність хіміка - як інтегрована сукупність знань, умінь, навичок і мотивів. Зокрема, виявлено недостатність вивченості питання професійної підготовки майбутніх хіміків у закладах вищої освіти. Здійснено аналіз Стандарту вищої освіти України першого (бакалаврського) рівня спеціальності 102 «Хімія» та з'ясовано, щзо експериментальний складник професійної діяльності хіміка посідає провідне місие. Зазначено, щуо педагогічні умови формування професійної підготовки хіміків мають бути спрямовані на формування експериментальних умінь. Визначено, що професійна компетентність майбутнього хіміка відбувається в умовах постійної експериментальної індивідуальної й групової діяльності. Формування професійної компетентності в майбутнього хіміка має відбуватися в спеціально створеному освітньому середовищі, провідним видом діяльності в якому буде виконання хімічного експерименту з дотриманням усіх вимог. У результаті проведеного пілотажного опитування викладачів закладів вищзої освіти й на основі власного досвіду визначено низку педагогічних умов, які сприятимуть підвищенню ефективності освітнього процесу та формуванню професійної компетентності хіміків на належному рівні. Зокрема, до таких педагогічних умов зараховано диференціацію навчання, індивідуалізацію освітньоі траєкторії навчання, визначення змістових ліній професійної підготовки, інтеграчію базової та діяльнісної підготовки, поступове зростання експериментальної самостійності студентів, орієнтування вибіркових дисичплін на набуття первинного професійного досвіду. Визначено перспективи майбутніх досліджень.

Ключові слова: професійна підготовка, компетентність, професійна компетентність хіміка, педагогічні умови формування професійної компетентності.
\end{abstract}

Olena EVDOCHENKO, orcid.org/0000-0001-6338-5372

Graduate Student at the Department of Pedagogy, Professional Education and Management of Educational Institutions Zhytomyr Ivan Franko State University (Zhytomyr,_Ukraine)evdochenko_lena@ukr.net

\section{FUTURE CHEMISTS' PROFESSIONAL TRAINING AS A PEDAGOGICAL ISSUE}

The article deals with a theoretical analysis and a differentiation of the "professional chemists' training", "professional competence" and "pedagogical conditions for chemists 'professional competence formation" notions. It is emphasized that despite the significant number of publications devoted to the notions study of the "professional training", "professional competence" and "pedagogical conditions", there is an ambiguity of their interpretations in the scientific and pedagogical literature. In this study competence is defined as a certain level of competences, chemist's professional competence as an integrated set of knowledge, skills, abilities and motives. In particular, the lack of the professional training of future chemists' issue in higher educational establishments is determined. The Ukrainian higher education Standard of the first (bachelor's) level of specialty 102 Chemistry is analyzed and it is found out that the experimental component of professional chemist's training is of paramount significance. It is noted that the pedagogical conditions for the professional chemists' training formation should be aimed at experimental skills formation. It is determined that the future chemist's professional competence takes place under conditions of constant experimental individual and group work. The professional future chemist's competence formation should take place in specially created educational environment, and the chemical experiment implementation in compliance with all requirements will be groundbreaking. As a result of lecturers' pilot survey in higher educational establishments and based on their own experience, a number of pedagogical conditions have been identified that will help increase the efficiency of the educational process and chemists'professional competence formation at the appropriate level. In particular, such pedagogical conditions include: differentiation of 
education, individualization of educational trajectory, the definition of professional training semantic lines, basic and activity training integration, gradual growth of students' experimental independence, focusing on selective disciplines on gaining initial experience. Directions for future research are underlined.

Key words: professional training, competence, chemist's professional competence, pedagogical conditions for professional competence formation.

Постановка проблеми. В умовах реформування системи вищої освіти важливого значення набуває проблема підготовки мобільних, висококваліфікованих, конкурентоспроможних фахівців різних галузей. Сучасним підприємствам необхідні працівники, які не просто отримали теоретичні знання в закладі вищої освіти, а й володіють гнучкими професійними вміннями та навичками, що дають їм змогу максимально швидко й ефективно адаптуватися до умов праці та успішно виконувати свої професійні обов'язки. Хімічна галузь постійно потребує таких фахівців, оскільки розвиток сучасних технологій, хімічної науки, методів і засобів дослідження, комунікацій вимагає від них володіння активними, трансформативними професійними вміннями.

Сучасна концепція організації підготовки майбутніх фахівців хімічної галузі пов'язана 3 побудовою наскрізних змістовних ліній, інтегруванням їх у єдину структуру, виокремленням основних етапів професійної підготовки та логічного взаємозв'язку обов'язкових компонент підготовки.

Аналіз досліджень. Професійна підготовка майбутніх фахівців різних галузей активно досліджується вітчизняними й зарубіжними науковцями. Сьогодні існує декілька підходів до іiї розгляду. Так, загальні питання професійної підготовки фахівців висвітлені в працях М. Бакум, С. Гончаренко, К. Корсака, В. Кушнирук, А. Лігоцького, В. Лугового, П. Олійника, В. Осадчого, М. Лещенка; обгрунтування доцільності спеціальної підготовки кадрів, визначення ії змісту, форм, методів, умов і специфіки професійної підготовки знаходимо в працях Є. Барбіної, С. Вітвицької, І. Зязюна, В. Лозової, Г. Касяновича, Н. Ничкало, Л. Романишиної, О. Романовської. У літературі також описані особливості професійної підготовки фахівців, обов'язковим для яких є оволодіння основами хімічної науки. Зокрема, професійну підготовку вчителів хімії досліджують А. Блажко, В. Богатиренко, А. Грабовий, Н. Прибора, Н. Шиян, О. Ярошенко; спеціалістів фармації - Б. Зіменковський, Л. Кайдалова, В. Черних, І. Бойчук, В. Сліпчук; фахівців аграрної галузі - Л. Білан, Л. Кліх, О. Нагорнюк, Н. Бурмакіна; професіоналів харчової галузі - Т. Лазарєва, М. Лобура, Л. Крайнюк, О. Туриця, О. Мельник. Професійну підготовку майбутніх хіміків в літературі описано недостат- ньо, розглядаються відокремлені елементи підготовки, відсутня педагогічна система професійної підготовки майбутніх хіміків, адже найчастіше хіміків готують саме висококваліфіковані фахівці хімічної галузі, а не педагоги, що й пояснює недостатню увагу до педагогічної проблеми професійної підготовки хіміків у закладах вищої освіти.

Мета статті - провести аналіз і визначити сутність, взаємозв'язок і взаємозумовленість понять, які становлять науково-теоретичне підгрунтя проблеми професійної підготовки хіміків у закладах вищої освіти; визначити основні педагогічні умови професійної підготовки майбутніх хіміків, які забезпечать формування їхньої професійної компетентності.

Виклад основного матеріалу. Провідним поняттям дослідження $\epsilon$ «професійна підготовка майбутніх хіміків», тому існує потреба в його тлумаченні. У Словнику термінів із загальної та соціальної педагогіки А. Вороніна поняття «підготовка» трактується як «формування та збагачення знань, умінь, необхідних індивіду для адекватного виконання завдань» (Воронін, 2006: 78). Академік Н. Ничкало визначає «підготовку» як загальний термін стосовно прикладних завдань освіти «коли передбачається засвоєння певного соціального досвіду 3 метою його подальшого застосування під час виконання специфічних завдань практичного, пізнавального чи навчального характеру» (Гончаренко, 2000: 101). Це поняття трактується у двох значеннях: як готовність - наявність сукупності знань, умінь, навичок (компетенцій), які забезпечують успішне виконання поставлених завдань, і як навчання - спеціально організований процес набуття готовності виконувати різноманітні завдання.

Підтримується така думка в роботі Т. Рогової, де професійна підготовка розглядається як система професійно значущих компетентностей і процес формування соціальної й професійної позиції, набуття готовності творчо виконувати професійні обов'язки (Рогова, 2015: 212).

Погоджуємося 3 думкою Н. Степанченко, яка наголошує, що професійна підготовка фахівців має бути безперервним процесом, який забезпечить набуття необхідного рівня знань, умінь, навичок, розвиток професійно й соціально важливих якостей, ціннісних орієнтацій; професійна підготовка реалізується в умовах освітнього 
середовища, створеного для набуття та розвитку сукупності професійних компетентностей; професійна підготовка - це результат освітнього процесу, набуття готовності до виконання професійних обов'язків (Степанченко, 2017: 88).

Під професійною підготовкою майбутніх хіміків у дослідженні будемо розуміти неперервний навчально-пізнавальний процес оволодіння необхідними загальними та спеціальними компетентностями хіміка, який відбувається в спеціально створеному освітньому середовищі шляхом реалізації низки педагогічних умов і забезпечує набуття знань, умінь, навичок, особистого ставлення, первинного досвіду, здатності успішно виконувати професійні обов'язки.

Загальні та спеціальні (професійні) компетентності хіміка визначені Стандартом вищої освіти України першого (бакалаврського) рівня спеціальності 102 «Хімія». Його аналіз показує, що майже половина $(45,45 \%)$ спеціальних компетентностей і програмних результатів (44\%) безпосередньо пов'язані 3 використанням експериментальних умінь у практичній діяльності. Майбутній хімік має вміти здійснювати типові лабораторні дослідження; виконувати кількісні вимірювання фізикохімічних величин, аналізувати отримані дані; використовувати стандартне обладнання; оцінювати можливі ризики своєї діяльності тощо (Стандарт вищої освіти, 2019). Тобто здатність застосовувати хімічний експеримент у всіх його проявах $\epsilon$ провідним видом професійної діяльності хіміка та, відповідно, методом володіння нею.

Ми дотримуємося думки С. Скарбич, що «компетенція» $\epsilon$ ідеальною метою освітнього процесу, яка визначає якості майбутнього фахівця, a «компетентність» - результат набуття компетенцій, рівень здатності виконувати завдання в нестандартних умовах. Поняття «компетенція» пов'язане зі змістом сфери діяльності, а «компетентність» - $з$ особистістю (Скарбич, 2011: 57).

Компетентність будемо розглядати «як специфічну здатність до продуктивної діяльності в конкретній предметній галузі, яка включає вузько спеціалізовані знання, уміння й навички, досвід їх використання в реальному житті, відповідальне ставлення до виконання виробничих функцій» (Вітвицька, 2015: 149).

Професійній компетентності в науковій літературі надають різні категорійні ознаки. Зокрема, професійну компетентність визначають як здатність, як характеристику особистості, як синтез компетентностей, як характеристику діяльності, як певний рівень реалізації компетенцій, як новоутворення (таблиця 1).
У дослідженні професійну компетентність хіміка будемо визначати як інтегровану сукупність знань, умінь, навичок, мотивів і способів реалізації діяльності, особистісних якостей, необхідних для успішної реалізації професійних обов'язків, яка формується в спеціально створених умовах освітнього процесу.

Визначаючи експериментальну діяльність провідною в професійній підготовці хіміка, можемо стверджувати, що професійна компетентність нерозривно пов'язана 3 опануванням здатностей раціонально планувати й організовувати хімічний експеримент, безпечно виконувати його, аналізувати отримані результати, формулювати висновки відповідно до цілей дослідження. Тому формування професійної компетентності майбутнього хіміка має відбуватися в умовах постійної експериментальної роботи, як індивідуальної, так і групової. Саме виконання експерименту як елементу наукового дослідження дасть змогу майбутнім хімікам у процесі виконання професійних обов'язків активно та мобільно використовувати набуті експериментальні вміння як професійно важливі.

Отже, набуття професійної компетентності майбутнім хіміком потребує створення спеціального освітнього середовища, провідним видом діяльності здобувачів вищої освіти в якому буде виконання хімічного експерименту. Створення такого середовища можливе через реалізацію низки педагогічних умов. Розглянемо категорію «педагогічні умови» в контексті професійної підготовки майбутнього хіміка.

У педагогічній літературі існує декілька трактувань поняття «педагогічні умови». Найчастіше педагогічні умови визначають як сукупність взаємопов'язаних передумов - матеріально-технічного, організаційно-технічного, кадрового забезпечення; як обставини процесу навчання й виховання; як чинники освітнього середовища.

Дослідники (Ю. Бабанський, М. Звєрів, I. Зязюн, I. Підласий) пов'язують педагогічні умови 3 конструюванням освітньої системи, у якій вони є структурним елементом. Інші науковці розуміють педагогічні умови як сукупність об'єктивних можливостей і заходів, необхідних для ефективної реалізації освітнього процесу (А. Найн, О. Федорова, В. Андрєєв, Н. Яковлєва, В. Жернов), або як сукупність зовнішніх і внутрішніх впливів (В. Манько, В. Полянський). Побутує думка, що умови - це педагогічні обставини, за яких компоненти освітнього процесу найкраще взаємодіють (О. Бережнова). Ю. Гвоздецька розглядає педагогічні умови як сукупність об'єктивних можливостей змісту, методів, органі- 
Пемагогіка

Таблиця 1

Категорійні ознаки компетентності

\begin{tabular}{|c|c|c|}
\hline $\begin{array}{c}\text { Категорійні ознаки } \\
\text { компетентності }\end{array}$ & Визначення & Автор \\
\hline \multirow[t]{2}{*}{ Здатність } & $\begin{array}{l}\text { Ефективно використовувати професійні знання, уміння, досвід } \\
\text { та особистісні якості для забезпечення необхідного результату } \\
\text { на конкретному робочому місці в певних обставинах }\end{array}$ & С. Гончаренко \\
\hline & $\begin{array}{l}\text { Застосовувати знання, уміння, навички, досвід, набуті особис- } \\
\text { тим шляхом освіти й практичної діяльності для розв'язання } \\
\text { проблем професійного характеру }\end{array}$ & В. Калінін \\
\hline \multirow[t]{3}{*}{$\begin{array}{l}\text { Характеристика } \\
\text { особистості }\end{array}$} & $\begin{array}{l}\text { Інтегративно-змістова, комплексно-структурована характерис- } \\
\text { тика, що поєднує сукупність знань, умінь, навичок, ціннос- } \\
\text { тей та особистісних характеристик, завдяки яким особистість } \\
\text { виконує професійні обов’язки відповідно до характеристик } \\
\text { кваліфікацій }\end{array}$ & 3. Шарлович \\
\hline & $\begin{array}{l}\text { Інтегративна характеристика знань, умінь, навичок, особистіс- } \\
\text { них якостей, яка визначає готовність фахівця до певного роду } \\
\text { діяльності }\end{array}$ & А. Шишко \\
\hline & $\begin{array}{l}\text { Інтеграція професійних знань, умінь, навичок, досвіду, що } \\
\text { забезпечують здатність фахівця виконувати професійні } \\
\text { обов'язки відповідно до стандартів і нормативних документів }\end{array}$ & Н. Бурмакіна \\
\hline Синтез компетентностей & $\begin{array}{l}\text { Включає спеціальну компетентність, що визначається воло- } \\
\text { дінням власне професійної діяльності, і соціальну - володіння } \\
\text { соціальною відповідальністю за результати своєї професійної } \\
\text { діяльності }\end{array}$ & А. Маркова \\
\hline Характеристика діяльності & $\begin{array}{l}\text { Характеристика діяльності фахівця, що містить змістовий } \\
\text { (знання) та процесуальний (уміння) компоненти, головними } \\
\text { ознаками яких є мобільність знань, гнучкість методів профе- } \\
\text { сійної діяльності й критичність мислення }\end{array}$ & С. Демченко \\
\hline \multirow[t]{2}{*}{ Новоутворення } & $\begin{array}{l}\text { Складне інтегральне, інтелектуальне, професійне й особис- } \\
\text { тісне утворення, яке формується в процесі професійної підго- } \\
\text { товки фахівця та залежить як від теоретично-практичної підго- } \\
\text { товленості, так і від індивідуальних якостей, цінностей, змісту } \\
\text { й особливостей цієї діяльності }\end{array}$ & М. Волошина \\
\hline & $\begin{array}{l}\text { Інтегративне, цілісне новоутворення особистості, яке є резуль- } \\
\text { татом безперервної освіти, успішність освіти при цьому зале- } \\
\text { жить від низки сформованих у людини компетенцій, які сприя- } \\
\text { ють формуванню науково-професійних поглядів }\end{array}$ & I. Соколова \\
\hline
\end{tabular}

заційних форм і матеріальних можливостей педагогічного процесу, що забезпечує успішне досягнення поставленої мети (Гвоздецька, 2017: 63).

Педагогічні умови визначають як сукупність зовнішніх i внутрішніх чинників (факторів), що зумовлюють процес формування професійної компетентності майбутніх фахівців і забезпечать ефективність перебігу освітнього процесу. Зокрема, А. Литвин уважає, що педагогічні умови - це «комплекс спеціально спроектованих чинників впливу на зовнішні та внутрішні обставини навчально-виховного процесу, які забезпечують цілісність навчання й виховання в інформаційному середовищі закладу освіти відповідно до вимог суспільства; їх реалізація сприяє всебічному розвитку особистості, формуванню загальнолюдських i професійно важливих якостей, базових кваліфікацій, ключових, загальних і професійних компетентностей» (Литвин, 2013: 72).
У контексті дослідження ми визначили педагогічні умови як цілісну систему чинників освітнього процесу, яка реалізується через активну взаємодією всіх його учасників i відображає сукупність педагогічних і матеріально-технічних можливостей освітнього середовища для успішного набуття майбутніми хіміками професійної компетентності. Належне обгрунтування педагогічних умов освітнього середовища забезпечить ix ефективну інтеграцію в педагогічну модель професійної підготовки хіміків. Реалізація цієї моделі в практиці навчання дасть змогу здобувачам вищої освіти досягти необхідного рівня професійної компетентності, виконувати професійні обов'язки та сформує здатність використовувати хімічний експеримент як основний вид професійної діяльності.

На основі проведеного дослідження й аналізу провідної викладацької діяльності з'ясовано, що 
педагогічні умови професійної підготовки хіміків спрямовані більшою частиною на формування експериментальних умінь, тому в дослідженні визначені такі педагогічні умови:

- диференціація студентів академічних груп залежно від сформованості експериментальної компетентності в загальноосвітньому закладі середньої освіти (початковий рівень експериментальної здатності);

- інтеграція теоретичної базової та діяльнісної підготовки майбутніх хіміків;

- поступове зростання самостійності проведення хімічного експерименту в навчальній діяльності;

- реалізація змістових ліній розвитку експериментальних здатностей здобувачів вищої освіти протягом усього терміну навчання;

- побудова індивідуальної траєкторії професійної підготовки майбутніх хіміків, зокрема й експериментальної;
- орієнтація вибіркових дисциплін на набуття первинного професійного досвіду, важливого для першого місця роботи.

Висновки. Проблема формування професійної компетентності майбутніх хіміків у процесі професійної підготовки $є$ малодослідженою та актуальною для педагогічної науки. Аналіз стану вивчення професійної підготовки майбутніх хіміків свідчить про існування нагальної потреби теоретичного та практичного іiі вирішення шляхом розроблення педагогічної моделі, підгрунтя якої становитимуть педагогічні умови формування й розвитку експериментальних здатностей майбутніх хіміків як основа набуття професійної компетентності.

Перспективи подальших досліджень убачаємо в обгрунтуванні комплексу педагогічних умов формування професійної компетентності майбутніх хіміків у процесі професійної підготовки й експериментальній перевірці ефективності визначених педагогічних умов.

\section{СПИСОК ВИКОРИСТАНИХ ДЖЕРЕЛ}

1. Вітвицька С. С. Теоретичні і методичні засади педагогічної підготовки магістрів в умовах ступеневої освіти : монографія. Житомир : Полісся, 2015. 416 с.

2. Воронин А. С. Словарь терминов по общей и социальной педагогике : учебное электронное текстовое издание / под ред. Г. Д. Бухарова ; ГОУ ВПО УГТУ ; УПИ. Екатеринбург, 2006. 135 с.

3. Гвоздецька Ю. В. Педагогічні умови формування професійної компетентності майбутніх викладачів з основ технологій харчових виробництв у процесі фахової підготовки. Збірник наукових прачь. Серія «Педагогічні науки». 2017. Вип. 78 (3). С. 104-108.

4. Литвин А., Мацейко О. Методологічні засади поняття «педагогічні умови». Педагогіка і психологія професійної освіти. 2013. № 4. С. 43-63.

5. Мельник О. Ф. Формування професійної компетентності майбутніх техніків-технологів виробництва харчової продукції в процесі вивчення природничих дисциплін : дис. ... канд. пед. наук : 13.00.04. Житомир, 2017. 372 с.

6. Професійна освіта : навчальний посібник / уклад. С. У. Гончаренко та ін. ; за ред. Н. Г. Ничкало. Київ : Вища школа, 2000. $149 \mathrm{c}$.

7. Рогова Т. В. Проблема управління якістю освіти в науковій літературі та освітній практиці. Педагогіка та психологія : збірник наукових праць. Харків : Смугаста типографія, 2015. Вип. 51. С. 211-218.

8. Скарбич С. Н. Формирование исследовательских компетенций учащихся в процессе обучения решению планиметрических задач : учебное пособие. Москва : ФЛИНТА, 2011. 194 с.

9. Стандарт вищої освіти. База даних «Міністерство освіти і науки України». URL: https://mon.gov.ua/storage/ app/media/vishcha-osvita/zatverdzeni (дата звернення: 04.09.2019).

10. Степанченко Н. І. Система професійної підготовки майбутніх учителів фізичного виховання у вищих навчальних закладах : дис. ... докт. пед. наук : 13.00.04. Житомир, 2017. 629 с.

\section{REFERENCES}

1. Vitvy`cz ka S. S. Teorety 'chni i metody`chni zasady` pedagogichnoyi pidgotovky` magistriv v umovax stupenevoyi osvity' [Theoretical and methodical bases of pedagogical preparation of masters in the conditions of degree education.] Monografiya. Zhy 'tomy`r: «Polissya», 2015. 416 p. [in Ukrainian].

2. Voronin A. S. Slovar terminov po obschey i sotsialnoy pedagogike [Glossary of terms in general and social pedagogy]/ Uchebnoe elektronnoe tekstovoe izdanie / pod red. G. D. Buharova. - GOU VPO UGTU - UPI. - Ekaterinburg, 2006. 135 p. [in Russian].

3. Gvozdecz 'ka Yu. V. Pedagogichni umovy` formuvannya profesijnoyi kompetentnosti majbutnix vy'kladachiv $\mathrm{z}$ osnov texnologij xarchovy'x vy'robny'cztv u procesi faxovoyi pidgotovky' [Pedagogical conditions for the formation of professional competence of future teachers on the basics of food technology in the process of professional training] / Yu. V. Gvozdecz'ka // Zbirny'k naukovy`x pracz` [Xersons 'kogo derzhavnogo universy 'tetu]. Pedagogichni nauky', 2017. $\mathrm{Nr}$ 78(3). pp. 104-108 [in Ukrainian].

4. Ly'tvy'n A. Metodologichni zasady` ponyattya «pedagogichni umovy» [Methodological principles of the concept of «pedagogical conditions»] / A. Ly`tvy`n, O. Macejko // Pedagogika i psy`xologiya profesijnoyi osvity', 2013. Nr 4. pp. 43-63 [in Ukrainian]. 
5. Mel’ny`k O. F. Formuvannya profesijnoyi kompetentnosti majbutnix texnikiv-texnologiv vy`robny`cztva xarchovoyi produkciyi v procesi vy`vchennya pry`rodny`chy`x dy`scy`plin [Formation of professional competence of future technicianstechnologists of food production in the process of studying natural disciplines]: dy`s. kan. ped. nauk: 13.00.04. Zhy`tomy`r, 2017. 372 p. [in Ukrainian].

6. Profesijna osvita: navchal’ny`j posibny`k [Vocational education: a textbook] / Uklad. S. U. Goncharenko ta in. / Za red. N. G. Ny`chkalo. - K.: Vy`shha shkola, 2000. 149 p. [in Ukrainian].

7. Rogova T. V. Problema upravlinnya yakistyu osvity` v naukovij literaturi ta osvitnij prakty`ci [The problem of quality management of education in the scientific literature and educational practice] / T. V. Rogova // Pedagogika ta psy`xologiya: zb. nauk. pracz`. - X.: «Smugasta ty`pografiya», 2015. Nr 51. pp. 211-218 [in Ukrainian].

8. Skarby`ch S. N. Formy`rovany`e y`ssledovatel`sky`x kompetency`j uchashhy`xsya v processe obucheny`ya resheny'yu plany`metry`chesky`x zadach [Formation of research competencies of students in the process of learning to solve planimetric problems]: [ucheb posoby`e] / S. N. Skarby`ch - M.: FLY`NTA, 2011. 194 p. [in Russian].

9. Standart vy`shhoyi osvity` [Standard of higher education // Baza dany`x «Ministerstvo osvity`i nauky` Ukrayiny`» // [Elektronny`j resurs]. - Rezhy`m dostupu: https://mon.gov.ua/storage/app/media/vishcha-osvita/zatverdzeni (data zvernennya 04.09.2019) [in Ukrainian].

10. Stepanchenko N. I. Sy`stema profesijnoyi pidgotovky` majbutnix uchy`teliv fizy`chnogo vy`xovannya u vy`shhy`x navchal'ny'x zakladax [The system of professional training of future physical education teachers in higher educational institutions]: dy`s. doktor. ped. nauk: 13.00.04. Zhy`tomy`r, 2017. 629 p. [in Ukrainian]. 